Лаврик С. С., аспірант, Донецький національний університет імені Василя Стуса

\title{
АКТИВІЗАЦІЯ ІНВЕСТИЦІЙНИХ МОЖЛИВОСТЕЙ ДОМОГОСПОДАРСТВ У КОНТЕКСТІ ДЕТІНІЗАЦІЇ ЕКОНОМІКИ УКРАÏНИ
}

У статті досліджуються інвестиційні можливості населення, розглядаються проблеми, які стримують розвиток інвестиційної діяльності домогосподарств в Україні. Проаналізовано основні показники, що вказують на проблему у інвестиційному середовищі країни, серед них: прямі іноземні інвестиції, інфляція, темпи росту ВВП, кінцеві споживчі витрати, рівень реальних трудових доходів. Детально розглянуто структуру накопичень населення, їх розмір та терміни, визначено основні тенденції. Особлива увага була приділена можливим накопиченням поза банківських установ у валюті, проаналізовано продаж готівкової іноземної валюти фізичним особам.

У результаті проведеного дослідження було сформовано основні напрями, за якими може бути здійснена активізація інвестиційних процесів серед населення. Запорукою успішного залучення коштів населення із тіньової економіки може стати не тільки повернення довіри до банків, а і розвиток небанківських фінансових установ.

Нами встановлено, що для цього необхідно привести у відповідність законодавство, з метою захисту інтересів домогосподарств і підвищення надійності таких структур. Запропоновано переформатування ринку робочої сили, розвиток фондового ринку та створення регіональних програм підтримки інвестиційних проектів, як перспективні напрями підвищення інвестиційних можливостей домогосподарств.

Ключові слова: інвестиційні можливості, тіньова економіка, домогосподарства, детінізація, залучення коштів, інвестиційна діяльність.

Рис. 3, Табл. 1, Літ. 7

Лаврик С. C.

\section{АКТИВИЗАЦИЯ ИНВЕСТИЦИОННЫХ ВОЗМОЖНОСТЕЙ ДОМОХОЗЯЙСТВ В КОНТЕКСТЕ ДЕТЕНИЗАЦИИ ЭКОНОМИКИ УКРАИНЫ}

В статье исследуются инвестиционные возможности населения, рассматриваются проблемы, которые сдерживают развитие инвестиционной деятельности домохозяйств в Украине. Проанализированы основные показатели, которые указывают на проблему в инвестиционной среде страны, среди них: прямые иностранные инвестиции, инфляция, темпы роста ВВП, конечные потребительские расходы, уровень реальных трудовых доходов. Подробно рассмотрена структура накоплений населения, их размер и сроки, определены основные тенденции. Особое внимание было уделено возможным накоплением вне банковских учреждений в валюте, проанализирована продажа наличной иностранной валюты физическим лицам.

В результате проведенного исследования были сформированы основные направления, по которым может быть осуществлена активизация инвестиционных процессов среди населения. Залогом успешного привлечения средств населения из теневой экономики может стать не только возвращение доверия к банкам, а и развитие небанковских финансовых учреждений.

Нами установлено, что для этого необходимо привести в соответствие законодательство, с целью защиты интересов домохозяйств и повышения надежности 
таких структур. Предложено переформатирование рынка рабочей силы, развитие фондового рынка и создание региональных программ поддержки инвестиционных проектов, как перспективные направления повышения инвестиционных возможностей домохозяйств.

Ключевые слова: инвестиционные возможности, теневая экономика, домохозяйства, детенизация, привлечение средств, инвестиционная деятельность

Lavryk S.

\section{ENHANCING HOUSEHOLD INVESTMENT OPPORTUNITIES IN THE CONTEXT OF LEGALIZATION OF THE UKRAINIAN ECONOMY}

The article examines the investment opportunities of the population, discusses problems that hinder the development of household investment activity in Ukraine. The main indicators that indicate a problem in the investment environment of the country were analyzed, among them: foreign direct investment, inflation, GDP growth rates, final consumer spending, the level of real labor income. The structure of savings of the population, their size and terms are described in detail, the main trends are determined. Particular attention was paid to the possible accumulation outside the banking institutions in foreign currency. the sale of foreign currency in cash to individuals was analyzed.

As a result, the main directions in which the investment processes among the population could be activated were formed. The key to successfully accumulation public funds from the shadow economy can be not only the return of confidence in banks, but also the development of non-bank financial institutions.

We've established that it's necessary to bring legislation in line, in order to protect the interests of households and increase the reliability of such structures. The reformatting of the labor market, the development of the stock market and the creation of regional programs to support investment projects were proposed as promising areas for increasing the investment opportunities of households.

Keywords: investment opportunities, shadow economy, household, de-shadowing, legalization of economy, fundraising, investment activities

Постановка проблеми. Гостре питання тіньової економіки актуалізується 3 кожним роком все більше. Не зважаючи на постійну боротьбу з цим явищем, масштаби тіні залишаються на досить високому рівні і за різними оцінками сягають позначки до $40 \%$ ВВП. Цьому сприяє велика кількість факторів серед яких основну увагу ми приділяємо корупції, недовірі до влади та великій кількості готівки у оберті, яка забезпечує функціонування тіньового сектора. Зменшенню готівкових коштів в економіці не сприяє відсутність широких інвестиційних можливостей для населення, що могло б створити додаткові стимули для повернення тіньового капіталу в прозору економіку.

Аналіз останніх досліджень і публікацій. Вивченню даного питання присвячено наукові роботи Гейця В.М., Гнибіденка І.Ф., Колота А.М., Куценко В.І., Лібанової Е.М., Лісогор Л.С., Макарової О.В., Черенько Л.М., Чернюк Л.Г., Шаульської Л.В. та інших.

Визначення невирішених питань в обраній для дослідження проблемі.

Досі невизначеними залишаються питання функціонування деяких небанківських фінансових установ (наприклад дилінгових центрів) в Україні, спрощення процесу інвестування за кордон та повернення довіри як до банківської системи, так i до державних цінних паперів. Крім того, $\epsilon$ несформованою інвестиційна поведінка українських домогосподарств, поступаючись накопиченню та нецільовим витратам. 
Метою статті $є$ оцінка можливості залучення інвестицій домогосподарств України як один з напрямів детінізації економіки. У контексті досягнення поставленої мети передбачається розв'язати наступні завдання: дослідити структуру та динаміку заощаджень населення; визначити проблеми формування інвестиційної поведінки населення, основні бар'єри інвестиційних процесів в Україні для домогосподарств; з'ясувати роль та місце заощаджень населення у забезпеченні економічного зростання в країні, надати рекомендації щодо активізації ощадних процесів в Україні.

Виклад основного матеріалу статті. Потенціал домогосподарств у інвестиційній діяльності в Україні на разі $є$ недооціненим, не зважаючи на те, що це $є$ одним з важливих факторів всебічного розвитку реального сектора та каталізатором інноваційної діяльності. Перебудова на колії ринкової економіки та залучення до глобальної економіки вимагає від держави в цілому, та кожного українця окремо, також змінювати і траєкторію соціально-економічного розвитку, де населення виступає не лише у якості продуктивних сил, а ще і як активний стратегічний інвестор.

На разі, інвестиційний клімат в Україні залишається непривабливим для іноземних інвесторів через загострення воєнного конфлікту, політичних проблем постійних змін у податковому та бюджетному законодавстві. У 2018 р. прямі іноземні інвестиції в Україну склали 1121 млн. дол. США, що на 49\% менше відповідного попереднього періоду (рис. 1) [1]. Найбільш проблемним залишається реальний сектор економіки, який не здатен на разі забезпечити швидку окупність інвестицій, а від так залишається без необхідного фінансування і модернізації. Отже, залучення внутрішніх інвестицій може бути сильною альтернативою зарубіжному інвестуванню, що 3 поміж іншого спричиняє зменшення тіньової економіки, оскільки зменшення готівкових коштів прямо пов'язано із масштабами тіні в економіці. Крім того, амністія тіньових капіталів можлива лише через залучення їх шляхом інвестицій.

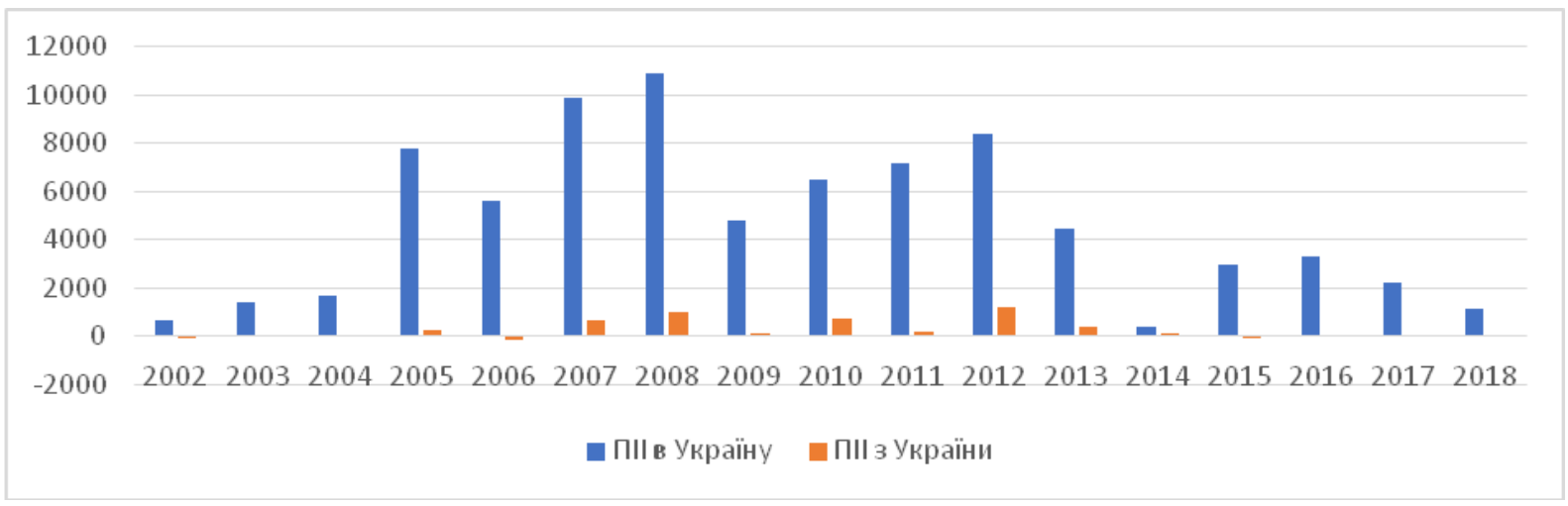

Рисунок 1 - Прямі іноземні інвестиції в Україні, 2002-2018 рр.

Сформовано автором на основі [1]

Досвід європейських країн свідчить про позитивний ефект від амністії через залучення вивезених капіталів до національної економіки шляхом інвестування у державні папери. Так у 2000-х роках у Бельгії, Люксембурзі, Ірландії та Італії широко застосовувалась дана практика як для бізнесу, так і домогосподарств, що в результаті повернуло від 2 до 60 млрд. євро . Акцент робився на одноразовості таких акцій, їх поєднання $з$ податковою амністією, а також посилення перевірок та санкцій після закінчення акції.

В Україні, на нашу думку, такі дії можуть бути ефективними, однак варто приймати до уваги непопулярність інвестицій під час війни та широку практику 
застосування офшорів для виведення капіталу з-під держконтролю, від так важливо не заміщати офшори амністією, а створити умови для утримання капіталів в країні шляхом спрощення легального функціонування фірми-резидента.

За роки незалежності України відзначається постійне зростання депозитів домогосподарств із сповільненням у роки кризи. У значній мірі динаміка залежала від циклічності економічного розвитку, на які припадають зміни валютного курсу та політична нестабільність. Так за період 2000-2010 pр. номінально обсяг накопичень зріс майже у 40 разів. Аналіз загальних накопичень населення України на депозитах показав, що у 2017 р. відбувається збільшення довіри до банківської системи, в наслідок чого обсяг депозитів перевищив докризовий показник 2013 р., який $\epsilon$ орієнтовним, і становить 495,3 млрд. грн. [2]. Однак зазначимо, що у зв'язку із введенням воєнного положення у 10 областях країни та продовженням падіння курсу гривні важко дати позитивний прогноз на 2019 р.

Таблиця 1 - Розмір депозитів домогосподарств, залучених комерційними банками в Україні*

\begin{tabular}{|c|c|c|}
\hline \multirow{2}{*}{ Рік } & \multicolumn{2}{|c|}{ Депозити домогосподарств } \\
\cline { 2 - 3 } & Усього, млн. грн & в іноземній валюті, млн. грн \\
\hline 1995 & 616 & - \\
\hline 2000 & 6780 & 3299 \\
\hline 2005 & 73202 & 64860 \\
\hline 2007 & 167239 & 107844 \\
\hline 2008 & 217860 & 113016 \\
\hline 2009 & 214098 & 132169 \\
\hline 2010 & 275093 & 149860 \\
\hline 2011 & 310390 & 182493 \\
\hline 2012 & 369264 & 184122 \\
\hline 2013 & 441951 & 217275 \\
\hline 2014 & 418135 & 212019 \\
\hline 2015 & 410895 & 235075 \\
\hline 2016 & 444676 & 242874 \\
\hline 2017 & 495313 & \\
\hline \multirow{2}{*}{ *фформовано автором на основі [2] } & \\
\hline
\end{tabular}

Позитивним зрушенням є скасування фіскальних зборів з обмінних операцій, що призвело до зростання в березні 2017 р. обсягу купівлі валюти населенням в банках у 1,84 рази (до 265 млн. дол. США) у порівнянні з січнем 2017 р., і в 6,66 рази в порівнянні з березнем 2016 р., коли збір існував [3].

Окрему увагу хочеться надати зміні тенденцій сальдо продажу готівкової іноземної валюти фізичним особам (рис. 2). Для України є характерною картина, спадаючого графіка у першому півріччі, та зростаючого - у другому. Однак, протягом 2018 р. спостерігається переважання нетто-продажу валюти домогосподарствам у порівнянні із 2017 р., (на 17,4\% за період січень-жовтень) з чого можна зробити висновок про зростання запасів готівкової валюти i розширення неформального сегменту валютного ринку. 
В результаті, це призводить до взаємозалежного лавиноподібного зменшення ліквідності національної валюти, тобто чим більша доларизація, тим менше вартість гривні, що спонукає надалі зберігати накопичення у валюті. Особливе пожвавлення схильності фізичних осіб до заощаджень у валюті пояснюється бажанням диверсифікації накопичень та зменшення ризиків. Наш аналіз вказує на те, що незважаючи на девальваційні очікування населення, на даний момент все ж переважають заощадження у національній валюті. Ми вважаємо, так відбувається за рахунок високої ліквідності гривневих вкладів (ставка відсотку від 16 до 20, у залежності від банку) у порівнянні із валютними (від 3 до 6 відсотків), хоча доля останніх постійно зростає. Вирішенням цієї проблеми може бути подальша боротьба із доларизацією і запасами готівкової валюти шляхом подолання чорного ринку валюти.

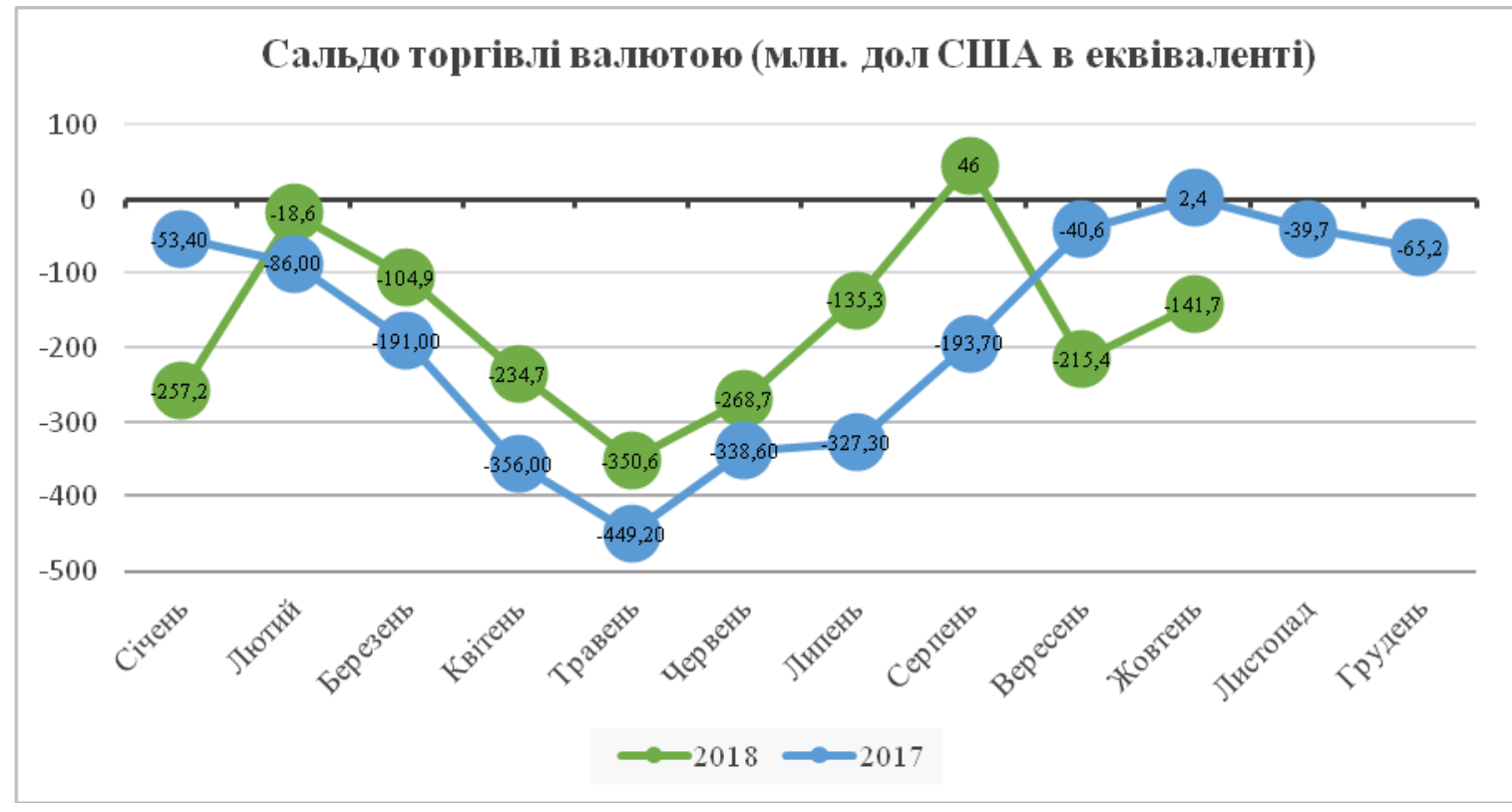

Рисунок 2 - Сальдо готівкової іноземної валюти, проданої фізичним особам за період

Сформовано автором на основі [3] 2017 - $2018 \mathrm{pp}$.

Проводячи аналіз заощаджень за термінами погашення, зазначимо, що у переважній більшості випадків населення віддає перевагу короткостроковим вкладам, що, на нашу думку, пояснюється збільшенням споживчих витрат, низькою довірою до банківських установ та необхідністю повернення непогашених кредитів.

Для подальшого нарощування потенціалу інвестиційної діяльності населення важливим фактом було зниження інфляції протягом 10 місяців 2018 р. до 107, 1\%, що на 4,4\% менше відповідного періоду у 2017 р. [4]. Однак, відмітимо значне подорожчання транспортних послуг і комунальних платежів із відсутністю реальної індексації соціальних виплат і заробітних плат.

Для дослідження інвестиційних можливостей домогосподарств необхідно розглянути такі індикатори як: інвестиційні мотиви, джерела інвестування, нагромаджений потенціал та економічна основа його формування (рис. 3), разом із відмінностями України та розвиненими країнами.

До основних факторів, що стримують розвиток інвестиційної діяльності серед домогосподарств слід віднести: 
— неконкурентний рівень заробітних плат, низький рівень оплати праці висококваліфікованих робітників у порівнянні із роботою яка не потребує особливих навичок і знань, найнижча серед європейських країн вартість робочої сили;

- відсутність справедливої пенсійної системи, яка б забезпечувала високий рівень життя, адекватний трудовому внеску громадянина;

- високий рівень тінізації економіки на всіх рівнях, велика кількість шахраїв, які позиціонують себе як інвестиційні компанії;

— збереження значних заощаджень домогосподарств поза межами банківської системи;

- практично повна недієвість небанківських структур, які б забезпечували швидке залучення вільних коштів населення в економічний обіг;

- несформованість у населення ментальності інвестора вітчизняної економіки, відсутність мотивації до інвестування [5].

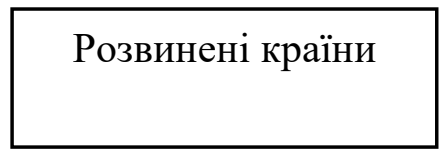

Ведення бізнесу

Диверсифіковані

Партнерські

Високий

Надзвичайно висока
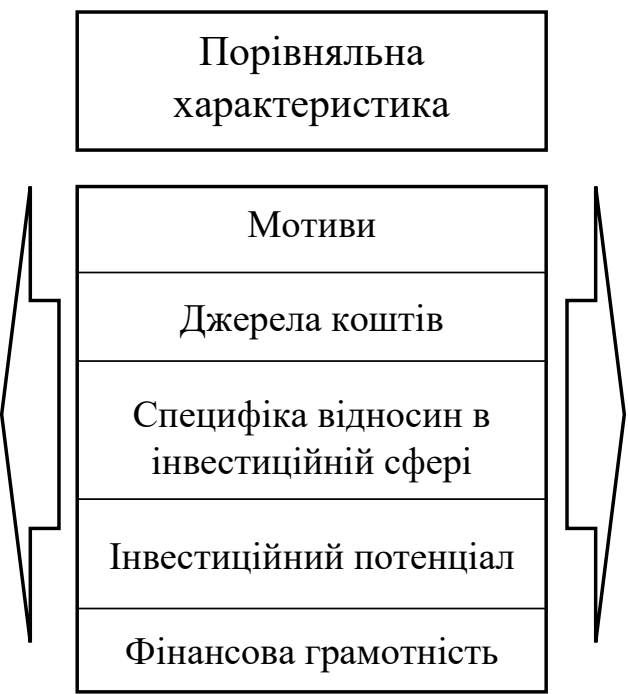

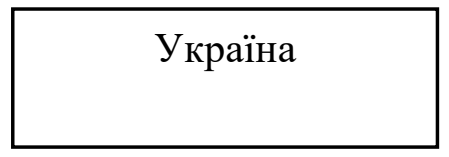

Виживання

Недиверсифіковані

Патерналістські

Низький

Низька

Рисунок 3 - Аналіз інвестиційної поведінки домогосподарств Сформовано автором на основі [5]

Поміж інших напрямів інвестування вільних коштів населення, крім депозитів, варто виділити малий бізнес або приватне підприємництво та нерухомість, разом із прибутком від оренди. Частіше за все, така діяльність існує за рахунок оформлення кредитів (іпотечного кредиту) з урахуванням ризику проекту. Банки також долучаються до акумуляції коштів населення і пропонують великий спектр продуктів і послуг, як то: операції з державними цінними паперами, операції з корпоративними облігаціями, муніципальними облігаціями та облігаціями банків; операції з векселями; операції 3 акціями [6]. Проте, ринок цінних паперів в Україні на разі стримується недосконалістю, нестабільністю та суперечливістю законодавчої бази, яка регулює його та суттєвими бюрократичними бар'єрами започаткування та провадження інвестиційної діяльності із цінними паперами. Крім того, дохід від такої діяльності часто не покриває потенційні ризики, які можуть виникнути в умовах нестабільної економічної ситуації.

Окрім банківських установ, населення може розміщувати свої заощадження у небанківських кредитних установах. Важливим інструментом для збереження i накопичення заощаджень українців $є$ недержавні пенсійні фонди, інститути спільного інвестування, страхові компанії та інші небанківські фінансові інститути, які пропонують населенню різні види послуг. Проте, як було зазначено раніше, ці 
інститути на разі не мають широкого поширення, а страховий ринок для фізичних осіб, на нашу думку, лише на стадії зародження в Україні. Для популяризації цих установ необхідно приведення законодавства у відповідність до європейських стандартів у частині контролю за функціонуванням, що створить умови для гарантування захисту заощаджень населення на високому рівні і забезпечить підвищення ступеня довіри до них.

Помірному пожвавленню інвестиційної активності може сприяти зростання кінцевих споживчих витрат на 4,2\% у II кв. 2018 р. у порівнянні до відповідного кварталу попереднього року та відновлення внутрішнього споживчого попиту. Приріст реального (на 2,8\% у III кв. 2018 р. порівняно з III кв. 2017 р.) та номінального (на 17\% у II кв. 2018 порівняно з відповідним періодом 2017 р.) ВВП України виявився недостатнім. Темпи приросту у реальному секторі не відповідають зростанню номінального ВВП, так наприклад оборот роздрібної торгівлі збільшився лише на 5\% відповідно до 2017 р., а індекси промислової та будівельної продукції лише на 1,4\% та 5,8\% відповідно [7].

Іншою причиною стримування інвестиційних можливостей населення безумовно можна вважати низький рівень реальних трудових доходів. Наявний дефіцит бюджету, внутрішній і зовнішній борг держави обмежують фінансові можливості держави утримувати життєвий рівень населення на високому рівні, від чого, в свою чергу, залежить його інвестиційний потенціал.

Крім того, необхідним є переформатування залучення тимчасово незайнятого населення до продуктивної праці з урахуванням низької потреби реального сектора економіки у трудових послугах та скороченням працевлаштування незайнятих осіб 3 одержанням офіційних доходів. Вирішенням може бути ініціація нових програм, що збільшують місткість сфер зайнятості населення через створення нових робочих місць.

Все це дозволяє зробити висновок, що інвестиційні можливості населення розвиваються у тісному зв'язку із загальнодержавними тенденціями інвестування. Однак на нашу думку, можливість залучати кошти домогосподарств через небанківські фінансові інститути якісно відрізняє їх від інших джерел інвестування. Ми вважаємо цей напрям найбільш пріоритетним для стимуляції інвестиційних процесів із залученням домогосподарств, оскільки функції які вони виконують (збереження і примноження заощаджень) лежать у полі зацікавленості сучасного українця. Для цього необхідно забезпечити високий рівень розвитку і надійності сучасних інститутів спільного інвестування, активно залучати до них населення через збільшення ролі муніципалітетів у формуванні мотивації, відповідного менталітету та створення регіональних програм, які б мали на меті розвиток системи маркетингу та промоції інвестиційних процесів. Продовжувати розвивати інфраструктуру підтримки інвестиційної діяльності, підвищувати зацікавленість внутрішнього інвестора. Забезпечувати фінансування програм та заходів з провадження інвестиційної діяльності в регіонах.

Висновки 3 даного дослідження. Зростання інвестиційних можливостей в Україні стримується низкою проблем, однак вдалося встановити, що є позитивні зрушення на шляху до переформатування домогосподарств у активного стратегічного інвестора. Крім того, така діяльність позитивно вплине на фактори, що призводять до зменшення тіньової економіки. Під час аналізу, основними напрями, за якими можна вдосконалити інвестиційну діяльність, було визнано підняття загального рівня життя населення, підвищення реальних заробітних плат, створення додаткових робочих місць, покращення роботи муніципалітетів метою 3 підтримки інвестиційної діяльності. 
Особливу увагу варто приділити небанківським фінансовим установам, які мають потужний потенціал повернення тіньових капіталів до економіки, за умови довіри до них та забезпечення надійності їх роботи. Активізація визначених напрямів вимагає розробки національних програм, орієнтованих модернізацію економічної бази розвитку домогосподарств, підвищення продуктивності їх функціонування в сучасному економічному просторі.

Перспективи подальших досліджень. Не вирішеними проблемами, які необхідно розв'язати з метою підвищення ролі заощаджень населення у зростанні національної економіки, є: відновлення довіри українців до банків, в результаті це б стимулювало перетік коштів із не спостережуваної до офіційної економіки із можливістю стати повноцінними інвестиціями через кредити, залучені у інноваційну діяльність та поновлення матеріальних фондів підприємств. Якщо в розвинених країнах найбільші частки приросту заощаджень фізичних осіб припадають на корпоративні цінні папери та страхові фонди, то в Україні їх спрямовують на депозитні рахунки комерційних банків або кредитування житлового будівництва, що спонукає нас до розвитку фондового ринку в Україні та ринкового середовища в орієнтації до залучення заощаджень населення.

\section{Література:}

1. «Національний банк оцінив обсяг коштів вітчизняного походження, які надійшли в Україну як прямі іноземні інвестиції в 2010-2017 роках» [Електронний ресурс]. Режим доступу: https://bank.gov.ua/control/uk/publish/article?art_id=73849831\&cat_id=55838

2. Національний банк України «Грошово-кредитна та фінансова статистика» https://bank.gov.ua/control/uk/publish/article?art_id=27843415

3. Національний банк України «Показники валютного ринку» [Електронний pecypc]. - Режим доступу: https://bank.gov.ua/control/uk/publish/category?cat_id=7693080

4. Державна служба статистики України [Електронний ресурс]. - Режим доступу: http://www.ukrstat.gov.ua

5. Інвестиційні можливості домогосподарств України: обмеження і перспективи / В. С. Заяць // Інвестиції: практика та досвід. - 2012. - № 5. - С. 4-6. Режим доступу: http://www.investplan.com.ua/pdf/5_2012/3.pdf

6. Рамський, А. Ю. Інвестиційний потенціал домогосподарств : монографія /А. Ю. Рамський. - К. : КНУТД, 2014. - 352 с

7. Аналіз показника валового внутрішнього продукту. [Електронний ресурс] / Фінансовий портал «МінФін» 2018 p. - Режим доступу: https://index.minfin.com.ua/economy/gdp/ 